\title{
"HINDRANCES IN THE EXERCISE OF FUNCTIONS" OF ADMINISTRATION: DEFECTIVE/ILLEGAL ADMINISTRATIVE ACTS, CONTROL MECHANISM
}

\begin{abstract}
The article discusses the issues of the availability and legal repercussions of illegal administrative acts according to Greek Administrative Law. Following the principle of legality, the operation of the public administration and especially the issuing of administrative decisions should be fully governed by the relevant legal provisions; nevertheless, it rather often happens that decisions are taken, which are partially or completely in violation of legal provisions. Despite that fact, and due to the existing principle of enforcement of administrative decisions independently of their legal status (presumption of legality of the administrative decisions issued), even illegal decisions are producing legal results and have to be removed or suspended in order to re-establish legality. The article presents various types and categories of problematic decisions. This issue is provided according to the theory of Administrative Law in Greece. In addition, the legal remedies foreseen for restitution of legality; the author considers other remedies and procedural functions, which can be applied either by the institutions themselves or by the citizens whose rights were negatively affected by the problematic decision.

Even though the situation at the legislative level seems to be satisfactory, the current manifold crisis of the country has led to the (pretty often conscientious) production of extremely defective and illegal decisions, the suspension of which requires time and resources. Whereas the citizens involved have to struggle to maintain their rightful status or even to survive socially and economically. The quantity of such decisions of the administrative and state institutions is reaching a threshold which can be considered risky and dangerous not only for the parties involved but in the medium-term also for the overall democratic structure of the country's executive and administration.
\end{abstract}

Key words: democratic and liberal rule-of-law states, principle of legality, Greek Administrative Law, administrative decisions, enforceable administrative decisions, presumption of legality, presumption of authenticity and originality, presumption of truth, procedure for challenging and annulling administrative decisions, void or non-existent administrative decisions, voidable administrative decisions, setting aside of a decision, judicial control of the legality of administrative decisions 
Dr. Stefanos Kareklas,

Team Leader of the EU-funded project "Promotion of the Rule of Law in the Kyrgyz Republic", attorney of Thessaloniki, Greece orcid.org/0000-0001-7998-7765 stefanos.kareklas@giz.de

\section{Introduction}

In the context of modern, democratic and liberal rule-oflaw state, the administration and its functions are limited by the law in terms of its activities not only in the negative sense; in the positive sense, the administration acts exclusively within the framework of legality and relies on the legality. The principle which plastically reflects the dependence of administration and institutions on the law is the principle of legality ${ }^{1}$. Through this principle, a chain between legislative and executive branches of power is created, hence, it is proceeded the responsibility of administration to focus on relevant legal instructions and respect them. Thus, the actions of administrative bodies should be based on legal provisions, which are issued legally by the elected government that, in its turn, forms people's sovereignty. Therefore, it is guaranteed the fundamental principles of democracy, social order, and public confidence in the government and its functions is consolidated.

The principle of legality and its absolute application should be (more or less) an ideal rule which aposteriori is subjected to exceptions: these exceptions, i.e. the actions of administrations on the edge of outside statutory limits or contrary to them may be plastically described as hindrances in the mechanism of functions of democratically legitimate and acting administration respectively; the above problems are the subject of the paper.

\section{On the concept "administrative act"}

Administrative authorities take particular actions for the everyday accomplishment of their mission: they render decisions, orders, certifications, instructions, expertise/ conclusions, reports. All these measures are the forms of manifestation of state, official authority and may be classified as an administrative act ${ }^{2}$. At the same time, the systematization of the matter of administrative law in Greece has contributed - so far as known it also takes place in France and Germany - to the limitation of the general definition on the so-called executive administrative act (technical concept of administrative act), i.e. the acts of administration which produce direct legal effects for

\footnotetext{
${ }^{1}$ See: Gerontas, aaO, p. 77.

${ }^{2}$ Ibid.
} 
citizens. The very acts differ from other decisions and documents of administration as they may be a subject of extensive control, including judicial because they touch upon the legal status and civil rights.

Greek administrative law attributes - mainly focusing on French and partially German law - not only individual but also regulatory acts to this narrow concept of the executive administrative act. In this context, despite the lack of definition of this phenomenon fixed by law, the concept of (individual) administrative act is defined as follows based on research data, direct legal provisions and judicial decisions: an individual administrative act is a sovereign act of an administrative body which regulates a particular case in accordance with the current administrativelegal provisions. It also includes the legal effects for citizens and has the authority of directs legal impact ${ }^{3}$.

Further, for a better comprehension of the range of problems concerning defective/ illegal administrative acts, it is essential to present the general properties of this (individual) act in brief and, at the same time, one should emphasize minimal criteria for its legal force and effectiveness.

A key factor for the above is, first of all, the issuance of an act by the responsible administrative body. Absolute compliance with the procedure of issuing act under the law is a necessary condition (conditio sine qua non) for a legal efficacy of the act; in almost all cases, it is formally stipulated that a drafted document is dated, issuing body is indicated, and the document is legally valid and signed. Specific procedures of the provision should be accurately observed depending on the case (for example, hearing of an interested party before the issuing an act).

A "legal substance" of administrative act marks that if the act is formally drawn up seamlessly then, eo ipso, it has the features of legality one and, as a rule, is subjected to be implemented. At the same time, many legal scholars qualify the mentioned executable nature not as a "feature" but as "actual substance" of the act".

Presumption of legality, within the frame of which it is accepted the primary legitimacy and direct enactment of the set legal effects of all acts, is the basic principle of administrative law. The legitimacy of the act is connected with state authority to a lesser degree and the principle of legal safety supporting the smooth and stable functioning of the administration and guaranteeing reasonable confidence of citizens in the legality of these functions, which are integral in a democratic state, to a greater degree ${ }^{5}$.

A critical moment for assessing the legality of administrative acts is the specific moment of its issuance which, among other things, should mean that subsequent amendments in its legal basis will not affect its legality if it is not prescribed by the relevant law and the constitution allows for contrary interference ${ }^{6}$.

\footnotetext{
${ }^{3}$ See Gerontas, aaO, p. 119.

${ }^{4}$ Ibid.

${ }^{5}$ See Gerontas, aaO, p. 79; Dagtoklou, aaO, p. 140.

${ }^{6}$ See Takhos, I.A., p. 582.
} 
The framework of presumption of legality includes two types of presumption, namely, the presumption of originality, which indicates the legitimate availability and functioning of the institution issuing acts; the principle of authenticity, which stipulates that facts mentioned in the act should be originally reliable. Both assumptions may be disposed because one can challenge all state documents concerning their falsification ${ }^{7}$. The basis of the presumption of legitimacy can be appealed with a proviso that a relevant administrative act is challenged within the term stipulated by the law. After the expiration of the specified term, the act can't be challenged, and presumption becomes uncontroverted. Thus, it is to be done both by citizens and administrative body. And vice versa, a successful refutation of the administrative act makes it null and void even ex tunc.

General principles concerning the implementation of activities of administration, as well as the serious assumptions in support of the issued administrative act, confirm that actual state of defective/illegal acts is the deviation from a normal function of the institution requiring thorough legal improvement. In Greek administrative law, which proceeds from French theory, it mainly influences the law (it is more correctly: it influenced as there has been a rise of influence of German legal sciences in recent times), and the study of defectiveness of the act is based on procedural criteria in the framework of appeal procedure and voidance in the State Council (Conseilcf Etat $)^{8}$. Nevertheless, it is admitted "pathology" of the act is not solely a procedural problem despite its direct connection with the procedural opportunities of appealing and specific judicial protection of the interested person. It raises the key issues, which in the context of their fundamental character, drastically touches upon the tangible parts of administrative law'.

\section{Defective administrative acts}

According to Greek administrative law, defective/illegal administrative acts are differentiated in the following way: a) originally invalid; b) genuinely invalid; c) acts subjected to cancellation. In the context of the theoretical distinction in law enforcement, including the practice of the State Council, there are no specific and definitive conclusions. From time to time, the above concepts are used nondifferentially thus, giving the wrong idea ${ }^{10}$.

a) originally invalid or non-existent administrative act means an act issued by a legal or physical person, who is not an official, e.g. rentier or legal person under private law. This refers to the illegal use of powers of an official because the official is not a representative of the body of administration, and "acts" which it issues can't be an expression of the sovereign state authority. And vice versa, such an act is out of the question if the issuing body, which is functioning legally or less legally, continues to manifest the features of the administrative body. In such cases, an official

\footnotetext{
${ }^{7}$ Greek Procedural Code, Arts. 438, 455.

${ }^{8}$ The Supreme Court on Administrative Cases.

${ }^{9}$ Dagtoglou, aaO, p. 295.

${ }^{10}$ Ibid.
} 
document should be evaluated superior to the fact of subsistence, since official acts evoke a sense of legitimacy and legality among citizens. If the defectiveness of act concerns the issues of abuse of powers (for example, fixing of taxes by a police officer, registration of marriage in a financial body), the issued act is originally considered to be invalid despite the issuing body is an expresser of state power and administrative law respectively. That sort of acts also has to belong to the acts whose issuance is not completed procedurally. Concerning legal effects, it is essential to mark the following special aspect: although the above-mentioned acts are legally defined as non-existent and thus, invalid, this fact doesn't need to be established and announced by the court; however, the judgment can announce them invalid if these acts, despite their legal non-existence, were executed by the administration, and it triggered changes in the real world. Exclusively the court is empowered to prescribe voidance of changes aroused in the external world.

b) and c) it is more difficult to draw the line between the invalid/null and void administrative act and the actsubjected to cancellation, as in either case the defectiveness is established in the same way. Although the null and void administrative act was issued by the administrative body, there was a violation of important legal provisions and rules. At the same time, the mentioned defectiveness may touch upon the formalprocedural or substantive rules. Further, an act is considered to be invalid/null and void if it originates as a consequence of wrong belief (a mistake of an official) or because the official was threatened with violence ${ }^{11}$. In legal terms, the invalid/null and void act is ineffective and is not obligatory for other administrative authorities and citizens. It can be appealed at any time by higher administrative authorities or the relevant courts. One should note that the decision of these authorities proclaiming invalidity/voidness of the act hasn't a constitutive nature but nominative one. It means that it is determined only available invalidity/voidness of the act, and this document is originally (ex tunc) null and void ${ }^{12}$. Compared to the above one, administrative act subjected to cancellation is an act which has defectiveness and thus, can be annulled. In such a case, the mentioned act is valid until its voidance and protected by the presumption of legality ${ }^{13}$. And if an act is not appealed within the time specified (as far as it goes, if there are no special rules for this act then, the timeframe is 60 days), it becomes valid. One of the examples of that sort of acts is acts which are based on the error of an administrative body issued the act. This misapprehension may have an actual nature (a mistake in the determination of composition error, error facti) and legal nature (error of law, error juris). The error of law may be a misinterpretation and application of pecuniary prescription which lies at the bottom of this act, while error facti touches upon the fact of the external world (for example, the identity of the affected citizen, the lack of key determinant etc.). Moreover, the act which is ground on the invalid prescription is also subjected to

\footnotetext{
${ }^{11}$ Gerontas, aaO., p. 181.

12 Ibid., p. $181 \mathrm{f}$.

${ }^{13}$ Takhos, aaO., p. 583.
} 
cancellation ${ }^{14}$. Null and void acts or acts subjected to cancellation can, in their nature, lead to the fact that only their part can be improper, and this can result in their partial illegality. In this case, other parts of the act independent of the disputed part continue to be valid. This refers to "separable/partial" acts, which partially are announced as invalid or void.

\section{Restoration of the rule-of-law}

In the democratic and liberal rule-of-law state, the administration should function legally, and the tolerance to any errors is out of the question. However, in real practice, the administration can issue improper acts while exercising its functions day to day. For this very reason, a particular regime should take place in terms of which an illegal act should be excluded and thus, legality should be restored. Naturally, there are widespread issues towards the democratic institutions of administrative bodies, their relatively strict hierarchy and duty of juniors to "pay heed" to the instructions of seniors in the area of control over illegal acts ${ }^{15}$. However, the subject of the current brief treaty is the consideration of illegal acts.

An illegal act can be: 1) repealed by the administration; 2) cancelled by the court; and 3) approved by the court.

The repeal of an act is the very administrative act issued chronologically later, which supersedes the force of previous act for the future or in retrospect. The issuance of such an act is followed by various prescriptions depending on the fact whether the repeal concerns compatible or illegal act. In the latter case, if the act is unfavourable to the interested individual/citizen (for example, collection of a monetary penalty, dismissal of an official etc.) the administration has an opportunity, according to the growing belief in the theory - duty ${ }^{16}$, to withdraw the act without temporal and other restrictions. This proceeds directly from the principle of legality, which is the basis of any actions of the administration. By contrast, the situation is not so clear when there is an illegal administrative act but favourable to the person concerned, because it gives him various rights. In this situation, there is a competition between the mentioned fundamental basic principle of legality and the equally solid principle of legal guarantee and fair confidence of "subordinated" person in the righteousness of actions of the administration. This subject is regulatory protected by the provisions of emergency law ${ }^{17} 261 / 1968$, which briefly stipulates that favourable individual acts

\footnotetext{
${ }^{14}$ Dagtoglou, aaO., p. 153.

${ }^{15}$ Only in the case of "obvious non-constitutional" ambiguous act, hierarchically inferior bodies are entitled to express their position and defeat the issuance of the non-constitutional act. If despite the arguments, a senior will insist on issuing the act, a senior shall act appropriately by completing the document with his comments. It doesn't affect the defectiveness of the act until the court determines it. Thus, there is nothing to do but to discuss the possible disciplinarytechnical state of affairs in part.

${ }^{16}$ Dagtoglou, aaO., S. 311.

${ }^{17}$ In the constitutional legal theory, such legal provisions are considered to be the emergency laws. The provisions are formally equal to the normal laws; however, they have been adopted beyond the framework of parliamentary procedures, not at the time of the abolition of democracy and related parliamentary system (dictatorships, military putsch, occupation).
} 
issued illegally shall be withdrawn within a reasonable period, and the mentioned reasonableness shall not exceed five years from the date of issuance of the act. The abovementioned provision, which originates from the time of the 1967-1974 military juntas, was sharply and fairly criticized for constitutionality ${ }^{18}$ after the restoration of democratic institutions in July 1974, but to this day it has not been changed. Criticism of this provision concerns the fact that the fundamental principle of fair confidence of citizens in the legality of functions of administrative bodies is formed temporarily and its appeal can continue ad infinitum (the five-year term is considered as the over-long temporal period to cancel an act). From the substantive perspective, this point is argued by the fact that in the democratic rule-of-law state, the maintenance of fair/sound confidence of citizens is worthier to be protected than the administration's right of cancellation; the argument which is greatly reputed in the relevant theory of France and Germany at all levels ${ }^{19}$. The author briefly specifies the consolidating practice of law enforcement of the State Council' ${ }^{20}$ : administration shall withdraw an administrative act, which is unlawful but favourable to a person interested, within the period specified. The time frames can be freely determined, but this period must be much shorter than five years from the date of act issuance. The fluctuations are admissible following the principle of strong public interest, or if defectiveness of the act is explained by unlawful behaviour, deviant behaviour of a beneficiary.

The repeal of an administrative act, which is unlawful but favourable to a person interested, is not unprofitable penalty but the restoration of violated legality; nevertheless, in theory, there is an opinion that the actions of the administration are also limited by the principle of proportionality ${ }^{21}$.

Administrative body, who has issued illegal administrative act, is responsible for its repeal or, in case of introduction of amendments to the law in terms of legal liability - a body which is responsible for issuing that sort of acts at the moment of their cancelling ${ }^{22}$. It is obvious that concern on contingent claims on compensatory damages to the beneficiary, who becomes a victim through the repeal of the act, and the matter of relevant responsibilities of administration on compensatory damages can't be even partially considered under the framework of this brief treaty - as it is declared by Arts. 105 and 106 of Greek introductory act to the Civil Code.

According to the Constitution, judicial review of the legality of administrative acts is the control objectives of general jurisdiction courts of individual administrative proceedings (Art. 94 of the Greek Constitution). In the context of a procedure of legality control, the case can concern the State Council on the ground of plea in

\footnotetext{
${ }^{18}$ See Dagtoglou, aaO., p. 315; Latsarotos, Constitutionality, p. 579 i.

${ }^{19}$ Ibid., p. $583 \mathrm{i}$

${ }^{20}$ See Gerontas, aaO., p. 173; thereinafter - Decisions of the State Council 2923/2006; 1567 i 3269-2010: 2414/2011 and 3/2013.

${ }^{21}$ See Latsarotos, Application, p. 534.

${ }^{22}$ See art. 21 para. 1 of Administrative Procedural Code, Law 2690/1999.
} 
abatement ${ }^{23}$. The possibility of submission of the mentioned plea by the interested person is stipulated by the Constitution ${ }^{24}$, and important details are regulated by an executive resolution of the President (Resolution 18/1989). Criteria for the commencement of an action that is specified by the provision in more detail, inter alia, deal with the legal nature of the act, legal interest of the person concerned, possible depletion of another legal remedy, different approaches in the case of claims relating to the responsibility of administration issued the act (for example, abuse of power) or in the case of doubt in substantive administrative law etc. If in the context of the repeal procedure, the claim is partially satisfied by the court and confirmed by the relevant decision, the administration is obliged to abide by the court's decision in practice immediately and announce the contested act or its part as null and void ${ }^{25}$. Although immediate execution of judgment is fixed by the Constitution, there are numerous occasions when the administration hasn't taken into account the constitutional postulate. That sort of situation has resulted in the fact that much of administrative courts in the country deal with the so-called enforcement cases daily. Moreover, even after such negative decisions, the execution on the part of administrative authorities is not fully guaranteed. And the situations when they are cancelled or overturned often take place that against the background of decisions crisis (supposedly) necessary to save government funds.

As the final result, it may well be that originally illegal act will be lately confirmed thus approved, and its illegality will be cancelled. This may happen due to the statutory change, issuance of the new act or judgment, which declares illegal act as legal and valid one that, as a rule, has a retroactive effect ${ }^{26}$.

\section{Practical case of the repeal of an illegal administrative act}

After much thought which was commenced in 2004, after the in-person revision in 2007, the Construction Department of Thessaloniki issued an administrative act which prescribes the demolition of expanded and illegally built balconies at two floors of a three-floored house. Besides, it is imposed a heavy fine for the constructing and conservation of illegal "construction elements and buildings".

The house was built legally in 1980 on a large plot owned by several possessors; there were some individual sites. In 1997, a division of all real estate was notarially undertaken, so individual property rights for each building proceeded from the originally common land plot. However, topographic scheme, which was attached to the contract, has invalid data related to one house that could create the impression that the balconies mentioned would be large enough and affect the adjacent sector. The invalid data, which could be notarially improved, was interpreted by the Construction Department as a construction disturbance that led to the issuance of a substantive inadequate administrative act.

\footnotetext{
${ }^{23}$ See Takos, aao., p. 783 i.

${ }^{24}$ See Art. 95 para. 1 of the Constitution.

${ }^{25}$ Art. 95 para. 5 of the Constitution.

${ }^{26}$ Takhos, aaO., p. 584.
} 
An interested person - the owner of the house - objected to the Construction Department regarding the demolition and the fine. There was talk not only about the fine amounting to near 70000 euro but also about the demolition of balconies which may infringe static stability of the whole house and thus, provide a victim with ruins as there is his apartmentin the building.

The objection was rejected by different divisions of the Construction Department, including superior ones; the administration continued to consider the balconies as illegal constructions which must be pulled down. The owner appealed to a higher authority, which all construction departments are subordinate to in the region of Central Macedonia (the first prefecture of Thessaloniki and other responsible regional authorities were involved while the case was been reviewing). The owner was lucky: the responsible authority, on request to the victim's petition, instructed to carry out a new revision, within the framework of which the defectiveness of the first image (topographic diagram) was established and thus, the fact of compliance with construction standards. The relevant administrative act was withdrawn without substitution (by the Construction Department at the order of the regional authorities). But since the administration did not make a serious mistake, the victim himself had to incur the expenses associated with the quasi-process, attorney's fees, etc. In the end, it was almost $40 \%$ of the amount of the previously imposed fine, in addition to the time (and other related ordeals of the victim), which was spent on the entire procedure (the final cancellation took place in 2010 - almost 6 years after the publication of the administrative act. If the regional authority also rejected the appeal, then the interested person would have only one way - litigation: the case would be considered to this day if the person had financial (such a way would be twice as expensive as administrative) and mental strength, if necessary) to visit all authorities and reach the State Council!).

\section{Topical challenges instead of epilogue}

Summing up the theory, an illegal act constitutes a deviation from the fundamental principle of legality; such an act must be repealed that the mentioned principle will be implemented in any case. In practice and till the legality is not be restored, the person concerned may suffer substantial damage that could trigger his collapse. This is evident in the tax sector. In order to preserve the common state institutions, that kind of state activity gained great significance over recent five-six years, especially against the background of the destructive, diversified and multi-layered crisis prevailing in the country. Departments dealing with the collection of taxes fulfil their state functions quite sharply, frighteningly and mercilessly towards a citizen. The constantly amassed and accumulated tax measures are quite often criticized by citizens in court; moreover, there are many judgments as well as decisions of the State Council declaring such measures (for example, extremely "horizontal" reduction of pensions) as unconstitutional. These measures are often designed in such a way they are rather rigidly directed against the vulnerable and low-income citizens that contributes to their marginalization. There is a big question concerning not only 
whether such political decisions and the individual notifications inherent to them comply with the law but, first of all, how they are fair, keeping in mind substantive standpoint, to go through judicial control successfully. Further, one can't ignore the fact that a legal dispute between a citizen and administration is not free of charge for the citizen, moreover, it is of some length that doesn't assist the citizen. And here the "Hamlet question" "to be or not to be" gains a special significance i.e. how long is it admissible - if it is admissible with reference to entirely extreme tax conditions and economic need challenging the state existence - to justify the cutting of legality and its violation in the interests of the well-known principle "the welfare of the people shall be the supreme law" ("salus patriae suprema lex ost"). Has Greece realized that deviation from the principle of legality indicated in the title of this paper as a "stumbling block" in the mechanism of administration functioning", which our democratic legislator intensively tried to find out and fix in a variety of different ways, become a standard? And can it even be recognized and legal? Where would the corresponding border be? In my opinion, the answer to this question is determining for the future of the country since it is my persuasion that in the framework of the most courageous discourse, justice will not be at the very end of the causal chain of injustices but will be a winner thanks to a meaningful and steady adherence to the rule of law.

\title{
References:
}

1. Dagtoglou, P.D (2014). Administrative law, $7^{\text {th }}$ revised edition, Anthem-Thessaloniki.

2. Gerontas, A. (2014). Collection of Administrative Law, Anthem-Thessaloniki.

3. Latsarotas, R. (2013). Use of the Fundamental Principles on the Repeal of Illegal Administrative Acts. Anthem, p. 531

4. Takhos, I.A (2015). Administrative law of Greece, $8^{\text {th }}$ edition, Anthem-Thessaloniki.

\section{«ПЕРЕШКОДИ В МЕХАНІЗМІ ФУНКЦІЙ» АДМІНІСТРАЦЇ̈: ДЕФЕКТНИЙ/ПРОТИЗАКОННИЙ АДМІНІСТРАТИВНИЙ АКТ, ЙОГО КОНТРОЛЬ}

\author{
Стефанос Кареклас, \\ керівник проєкту «Просування верховенства права в Киргизькій Республіці», \\ що фінансується ЄС, \\ адвокат у м. Салоніки, Грецька Республіка, \\ доктор права \\ stefanos.kareklas@giz.de \\ orcid.org/0000-0001-7998-7765
}

У статті обговорюються питання наявності та правових наслідків незаконних адміністративних актів згідно з Адміністративним правом Греції. Відповідно до принщипу законності діяльність державних адміністративних органів, зокрема прийняття адміністративних актів, має повністю регулюватися відповідними правовими положеннями; однак часто відбувається так, щзо приймаються акти, які частково 
або повністю суперечать правовим положенням. Незважаючи на це $i$ завдяки чинному принципу, можливості виконання адміністративних актів незалежно від їх правового статусу (прийнятої презумпиії законності щуодо адміністративних актів), навіть незаконні акти призводять до правових наслідків і повинні бути анульовані або їх дія повинна бути припинена з метою відновлення законності. У статті представлені різні види і категорії проблемних актів. Це питання було розроблене відповідно до теоріі Адміністративного права в Греції. Крім того, у статті розглядаються засоби правового захисту для відновлення законності, а також інші засоби захисту і правові функиії, які можуть бути застосовані самими установами або громадянами, чиї права були порушені проблемним актом.

Незважаючи на те, щзо ситуація на законодавчому рівні здається задовільною, поточна багатоаспектна криза в краӥні призвела (найчастіше свідомо) до складання безлічі вкрай неякісних інезаконних актів, призупинення дї̈яких вимагає часуі коштів, тоді як втягнутим у ие громадянам доводиться боротися за збереження свого законного статусу або навіть виживати із соиіальної та економічної точок зору. Кількість подібних адміністративних i державних установ наближається до порогового рівня, що може становити ризик і небезпеку не тільки для залучених сторін, але (у середньостроковій перспективі) також для всієї демократичної структури виконавчої влади і державного управління країни.

Ключові слова: демократичні і ліберальні правові держави, принцип законності, адміністративне право Греції, адміністративні акти, адміністративні акти, що підлягають виконанню, презумпція законності, презумпція достовірності й автентичності, презумпція істини, порядок оскарження та скасування адміністративних актів, недійсні або такі, втратили силу, адміністративні акти, спірні адміністративні акти, скасування акта, судовий контроль над законністю адміністративних актів. 